\author{
Anna Kozłowska \\ https:/ / orcid.org/0000-0001-6843-5981 \\ University of Lodz \\ Faculty of Geographical Sciences \\ Institute of Geography of the City and Tourism \\ anna.kozlowska@geo.uni.lodz.pl
}

\title{
THE GASTRONOMIC PRODUCT OF ŁÓDŹ HOTELS
}

\begin{abstract}
Restaurants and other facilities providing catering services are an important part of hotels, can be their flagship product or make them unique. The obligation to provide restaurant services was imposed by the Ordinance of the Minister of Economy and Labour of 19th August 2004, concerning hotel and other facilities where hotel services are provided. Despite the dynamic development of gastronomy in the $21^{\text {st }}$ century, running catering facilities in hotels is often an obligation which does not bring additional income.

The aim of the research is to present the gastronomic product in Lodz hotels, understood as all the services related to gastronomy that are provided. The analysis was conducted with respect to the brand of the facilities, references to local cuisine and the availability of hotel gastronomy to potential guests. The work also presents factors that may facilitate access to hotel gastronomy, breaking the stereotype of 'available only for hotel guests', as well as the advantages of using the hotel's gastronomic product in a proper way.
\end{abstract}

Keywords: gastronomic product of a hotel, hotel restaurant, Łódź, hotel gastronomy.

\section{INTRODUCTION}

The city of Łódź can boast some gastronomic events of long-standing reputation which have been held regularly for several years and are well known in Poland and other European countries. They include, Festiwal Dobrego Smaku (Festival of Good Taste) or Międzynarodowe Targi Żywności Ekologicznej i Naturalnej: Natura Food (International Organic and Natural Food Fair: Natura Food) (Kozłowska, 2015). At the same time, Łódź lacks culinary trails, while a regional cuisine and tourist products based on the culinary heritage of the city either do not exist or have not been sufficiently developed. In recent years, however, some positive changes have been observed. The number of restaurants and urban spaces clearly distinguishable on the culinary map of Poland has been gradually growing (Stasiak, 2015), particularly as regards facilities situated in historical interiors, such as the post-industrial buildings so characteristic of Łódź.

Hotel restaurants are usually associated with high standards and universality, their menus are prepared in such a way that they are suitable for different customers, regardless of where they come from or their cultural background.
All gastronomy-related services provided by hotels form the gastronomic product, which is a basic component of the hotel product, and the Tourism Services Act obliges hotel owners to provide at least basic gastronomic services (Ustawa, 1997). The gastronomic product consists of material components (manufactured goods) and non-material elements, including a wide range of hospitality functions, e.g. how services are provided, the times of service, knowledge of foreign languages and the hotel ambience (Milewska, Prączko, Stasiak, 2017). The gastronomic product includes all that satisfies the customers' appetites, as well as fulfilling other needs as well, e.g. the need to experience a different culture, admire interior designs, or visit a popular location (Stasiak, 2007).

The elements of the gastronomic product can be divided into three parts. The central, basic part is the product core (satisfying hunger), usually enriched with components increasing its value and attractiveness on the market. The next is the actual product, i.e. those elements which create the product and influence the way it is perceived by the customers (e.g. the price, the name of the dish, the way it is served, etc.). All the additional 
features and benefits (e.g. product accessibility, booking systems and methods of payment) build the augmented product (Milewska, Włodarczyk, 2015; Sala, 2011). Competition on the gastronomy market forces establishments to expand their offer by adding new attractive augmented product elements such as presence on social media and internet portals, enabling customers to have the food delivered, and new booking methods (on-line, by phone, through mobile applications). The elements of the augmented product present gastronomic establishments, distinguish them on the market and persuade customers to choose a given restaurant. This may bring substantial additional revenue and be a perfect opportunity to promote the hotel as a whole. Owners tend to include the organization of various events (e.g. wedding or funeral receptions, conference coffee breaks) in their offer using the hotel's dining facilities.

Hotel restaurants are different from others because, in most cases, they have to meet the requirements arising from being a hotel (Gordin, Trabskaya, Zelenskaya, 2016). When describing the gastronomic product, it is necessary to consider the hotel brand and its effect on the restaurant.

The author has reviewed the existing literature and concluded that there were no publications on hotel gastronomy in Łódź. The aim of the article is to describe the gastronomic product offered in Łódź hotels with respect to their location, accessibility to customers and the brand they represent. The author studied the influence of these factors on the attractiveness of the hotel gastronomy product in Łódź.

\section{LITERATURE REVIEW}

Gastronomy is rising in popularity, becoming an independent tourism product and not merely a supplement to the tourist offer or an additional service. Consumer awareness is growing alongside expectations from the dishes they are served, the interiors in which they have their meals and the way they are served. Many publications can be found on culinary tourism e.g. on regional cuisines, gastronomic tourist products and forms of organizing culinary tourism (Jędrysiak, Orłowski, Woźniczko, 2015; Kwiatkowska, Levytska, 2009).

In Poland, gastronomic issues are mainly presented theoretically, on the situation in foreign markets or data obtained from the Central Statistical Office. In 2015, Łódź hosted a conference entitled 'Culture and tourism: around a shared table' on the topic of gastronomy in the hotel industry. The authors of the conference publication stressed that 'relatively few articles are based on rudimentary empirical studies' (Stasiak,
Krakowiak, 2015, pp. 5-6). Foreign literature presents empirical studies of hotel gastronomy or specific gastronomic products, the importance of local cuisine in gastronomic offers and its impact on the region's brand (Björk, Kauppinen-Räisänen, 2017; Gordin, Trabskaya, Zelenska, 2016; Kapera, 2015). Reliable data is available, concerning the potential of culinary tourism (Stasiak, 2015) and the location of hotels (Włodarczyk, 2015) in Łódź. However, there is a lack of publications regarding hotel gastronomy.

\section{RESEARCH METHOD}

The author conducted her research at 33 categorized hotels in Łódź, from January to May 2018. The primary source of information about the hotels was www.turystyka.gov.pl. (Centralna Ewidencja i Wykazy w Turystyce, Ministerstwo Turystyki), and the data provided by the website was compared to the actual situation; in 2018, two mentioned were no longer functioning as hotels.

The original questionnaire consisted of four parts: the condition of the gastronomic facilities in the hotel, gastronomic services provided in multi-functional rooms, the hotel's marketing strategy with respect to gastronomy, and the restaurant's formal and financial dependency on the hotel. The survey was conducted in person, online and during telephone interviews. Five hotel administrators refused to take part in the survey. The questionnaires included information from official hotel websites.

In order to analyse the collected material, the author referred to the following: Ustawa $z$ dnia 29 sierpnia 1997 r. o ustugach hotelarskich oraz ustugach pilotów wycieczek i przewodników turystycznych (Hotel Services and Tourist Couriers' and Guides' Services Act of 29 August 1997) (Ustawa, 1997), Rozporzadzenie Ministra Gospodarki i Pracy z dnia 19 sierpnia 2004 r. w sprawie obiektów hotelarskich i innych obiektów, w których sq świadczone ustugi hotelarskie (Ordinance of the Minister of Economy and Labour of 19 $9^{\text {th }}$ August 2004, concerning hotel and other facilities where hotel services are provided) (Rozporzadzenie, 2004), literature on gastronomy and the hospitality industry, as well as TripAdvisor data (TripAdvisor). The map was prepared using ArcMapa 10.4.1., cartographic backgrounds were obtained from Łódź InterSIT website, WMS service (InterSIT).

\section{GASTRONOMY IN ŁÓDŹ HOTELS}

A hotel is defined as an accommodation facility with at least 10 rooms, mostly single or double, providing a number of services connected with a guest's stay 
Table 1. The standards of gastronomic services and facilities required in hotels

\begin{tabular}{|c|c|c|c|c|c|}
\hline \multirow{2}{*}{ Standards } & \multicolumn{5}{|c|}{ Hotel category } \\
\hline & $* * * * *$ & $* * * *$ & $* * *$ & ** & * \\
\hline Providing guests with the possibility of buying hot drinks 24 hours a day & $\mathrm{x}$ & $\mathrm{x}$ & $\mathrm{x}^{\mathrm{a}}$ & $\mathrm{x}^{\mathrm{a}}$ & $\mathrm{x}^{\mathrm{a}}$ \\
\hline Serving breakfasts & $\mathrm{x}$ & $\mathrm{x}$ & $\mathrm{x}$ & $\mathrm{x}$ & $\mathrm{x}$ \\
\hline Aperitif-bar or coffee bar & $\mathrm{x}$ & $\mathrm{x}$ & $\mathrm{x}$ & $\mathrm{x}$ & - \\
\hline $\begin{array}{l}\text { Restaurant (the lack of a restaurant is allowed in 3-star hotels if there is one available } \\
\text { within max. } 200 \text { metres from the hotel) }\end{array}$ & $\mathrm{x}$ & $\mathrm{x}$ & $\mathrm{x}$ & - & - \\
\hline Serving meals to residential unit - room-service available for at least 18 hours per day & $\mathrm{x}$ & $\mathrm{x}$ & $\mathrm{x}$ & - & - \\
\hline
\end{tabular}

a Available from either vending machines or at the reception.

Key: ' $x$ ' - mandatory, ' -' - not mandatory (optional).

Source: author, based on the Ordinance of the Minister of Economy and Labour of $19^{\text {th }}$ August 2004 concerning hotel and other facilities where hotel services are provided (Rozporzadzenie, 2004).

(Ustawa, 1997). One of the services available at hotels is the gastronomic service. Rozporzadzenie Ministra Gospodarki i Pracy z dnia 19 sierpnia 2004 r. w sprawie obiektów hotelarskich i innych obiektów, w których sa świadczone ustugi hotelarskie (Ordinance of the Minister of Economy and Labour of $19^{\text {th }}$ August 2004, concerning hotel and other facilities where hotel services are provided) defines the standards for individual hotel categories (Table 1), regarding facilities and the scope of services (Rozporzadzenie, 2004). The document states that the owner does not have the right to use the term 'hotel' if they do not provide gastronomic services.

The regulation states that five- to three-star hotels must include a restaurant as well as serve breakfasts and sell hot drinks (Table 1). Contrary to the Minister's ordinance, the Tourism Services Act does not contain a definition of a restaurant as a mandatory hotel amenity (Rozporzadzenie, 2004).

Milewska, Prączko \& Stasiak (2017) define a restaurant as an establishment available to any consumer, offering full waiter service and a wide selection of dishes and drinks listed on its menu. 1- and 2-star hotels are not required to include a restaurant or other catering facility, but they must provide breakfasts. The administrators meet this requirement by serving breakfasts either prepared on the spot or delivered by an outside catering company. They also cooperate with such firms when organizing coffee breaks during conferences or events such as wedding or christening receptions. An example is the Eskulap Hotel, which does not have kitchen facilities but has signed a contract with a catering firm which delivers breakfasts and organizes events in the hotel.

The 33 categorized hotels in Łódź offer a total of about 5200 beds (September 2018). Łódź does not have a hotel of the highest standard (5-star). The majority are 3-star (16) and 2-star (10) while there are also two 1-star and five 4-star hotels.

At the time of the research, 6 (18\%) out of 33 hotels did not feature a working catering facility (Fig. 1), including one 3-star hotel, which was being renovated at that time. The remaining 27 featured only two

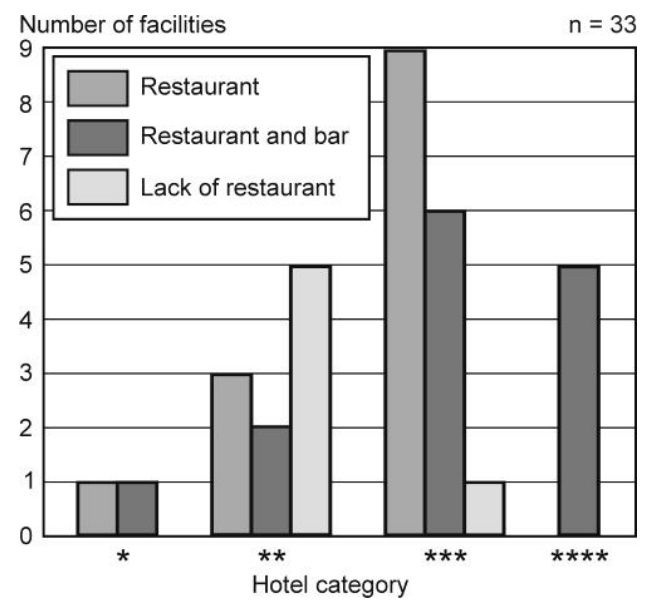

Fig. 1. Types of catering facility in Łódź hotels by hotel category Source: author, based on own research

types: a restaurant or a bar. None of the inventoried hotels had a facility open during the night considered in the literature to be popular (Sala, 2011). The Alicja Hotel was the only one to have a restaurant open solely for hotel guests.

The presence of catering facilities depends on the strategy chosen by a given hotel, its category or ownership status - restaurants may be run by outside cooperating firms, on agreed terms. An example is the well-known 'Lawasz' restaurant, at the Vigo Hotel in Łódź. Run as a separate business, it offers Caucasian-Polish cuisine to its customers. As a part of the agreement, the company's duties include preparing breakfasts, room service and catering during conferences.

\section{THE GASTRONOMIC PRODUCT BRAND IN ŁÓDŹ HOTELS}

The author studied restaurants and their brands in Łódź hotels, taking three factors into consideration: having its own name, being a part of a restaurant chain and being situated in a historical building. 
A brand is a name, symbol, logo or a combination, created to identify the establishment and easily distinguish it from the competition (Kotler, 1994). A coherent, well-made brand creates character and atmosphere, influencing its perception by guests (Wrona, Armatys).

If a hotel is a part of a system, the brand is associated with existing gastronomic establishments. The moot point is whether connecting the latter with either an independent hotel or a hotel chain brings benefits or is a barrier to potential restaurant guests. Belonging to a network may guarantee high quality of service, increase the popularity of the establishment due to, for instance, positive opinions about the hotel network, but it may also deter the customers with high prices (e.g. when the hotel network has a reputation for being expensive), or be associated with only one type of cuisine (e.g. international and not local). On the other hand, being part of an independent hotel may discourage consumers as they are not familiar with the brand and think the restaurant is available solely to hotel guests. Out of 33 hotels in Łódź, 18 (55\%) are affiliated - they belong to local networks (e.g. Ambasador hotels), Polish hotel systems (e.g. Qubus Hotels) and international chains (e.g. Accor Hotels).

In recent years, it has been a common practice to check the opinions and information about catering facilities or hotels on the social media. In this case, it is significant whether the restaurant belongs to a hotel network, or is under its own brand etc., because this builds a completely different online community and, depending on the situation, the hotel and the restaurant may work for the customers' trust either separately or together (Kachniewska, 2013). It remains controversial whether having a separate name (other than that of the hotel) brings more benefits, or does not matter for the guests. The lack of a name may be a barrier to potential customers, because social media will only provide information about the restaurant under the hotel's name. Joint activity of the restaurant and hotel may result in the lack of information about the former or difficulties in finding it (Grzegorczyk, 2005).

In Łódź, 11 out of the 27 restaurants presented in this article are under their own names (Fig. 2). No clear relationship between having such a name and belonging to a network is found: 5 out of 13 restaurants use their own name in independent hotels (e.g. the 'Stotówka' restaurant in the Mazowiecki Hotel), and, similarly, 6 out of 14 restaurants in affiliated hotels carry their own names (e.g. 'Restauracja Łódzka' in Holiday Inn). The Qubus Hotel (Qubus Hotel network) used to have a restaurant named 'Ogien' ('Fire'), but due to the standardization of the network's brand, the idea of separate names for the restaurant and the hotel was abandoned in 2018.

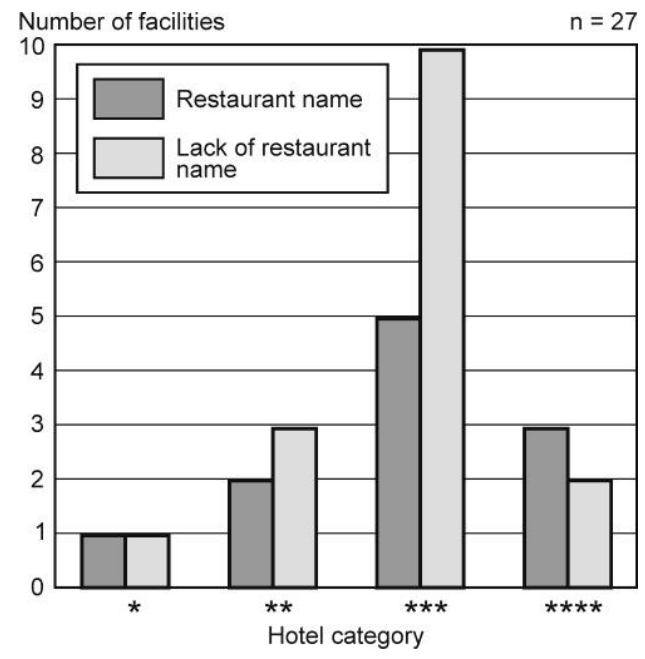

Fig. 2. Hotel restaurants by name Source: author

The basis for creating a restaurant brand may be its history or location in a historical building. According to the historical monuments register, in Łódź, there are seven hotels situated in $19^{\text {th }}$ and $20^{\text {th }}$ century buildings (Table 2).

At the moment, three out of seven hotels situated in historical buildings are not offering gastronomic services. An interesting case is the Grand Hotel, which is the only one functioning in a historical building that has not changed its function or name ever since it was established, i.e. for over 130 years. An additional attraction for customers using the restaurant could be to see the interiors of this legendary hotel, not available to outside visitors. Guests dining in historical interiors have an opportunity to see interesting architectonic details, admire the decor, learn about the history of the hotel and the city, and in this way feel the atmosphere of Łódź from former times (Grand Hotel Łódź).

\section{LOCAL CUISINE AS AN ELEMENT OF THE GASTRONOMIC PRODUCT}

Before World War II, Łódź had been a city of four cultures: Jewish, German, Russian and Polish. Their mixture was reflected in the local gastronomy, and the remnants of ethnic cuisines can still be found today (Stasiak, 2015; Wojciechowska, 2014).

Since 2004, the Polish Ministry of Agriculture and Rural Development has been running a program of promoting, supporting and protecting traditionally produced foodstuffs. In January 2019, the list comprised 1864 traditional and regional products, including 141 from Łódź Province łódzkiego (Ministerstwo Rolnictwa i Rozwoju Wsi). Unfortunately, products from 
Table 2. Hotels in historical buildings in Łódź

\begin{tabular}{|c|l|c|c|c|c|c|}
\hline No. & \multicolumn{1}{|c|}{ Hotel's name } & Restaurant & Established & $\begin{array}{c}\text { Previous function of } \\
\text { the building }\end{array}$ & $\begin{array}{c}\text { Date of entry } \\
\text { on the } \\
\text { historical } \\
\text { monument } \\
\text { register }\end{array}$ & Address \\
\hline 1. & Polonia & $\begin{array}{c}\text { No working catering } \\
\text { facility }\end{array}$ & 1910-1912, 1953 & 'Palast' Hotel & $1994-03-31$ & 52 Kilińskiego St. \\
\hline 2. & Reymont & $\begin{array}{c}\text { No working catering } \\
\text { facility }\end{array}$ & 1927 & military building & $1971-01-20$ & $81 / 83$ \\
Legionów St.
\end{tabular}

Source: author, based on register of historical monuments (Wojewódzki Urząd Ochrony Zabytków w Łodzi, 2018).

the list are not recognizable enough to be commonly associated with traditional Łódź cuisine.

Menus in many Łódź restaurants refer to the history of the city and its cultural heritage while dishes inspired by the city's past can also be found in hotel restaurants. The ' $U$ Kretschmera' restaurant in the Tobaco Hotel, refers to the history of Łódź not only through its name, but also through its cuisine. The dishes from the menu are inspired by traditional recipes, taking advantage of the culinary richness of various cuisines. 'Restauracja Łódzka' at Holiday Inn Łódź offers the guests a menu supplement, based on the book entitled 'Fifka and Żulik' (Dziennik Łódzki). Anna Wojciechowska, the author, collected recipes for traditional Łódź dishes, calling them the cuisine of the former factory workers in Łódź. The recipes presented in the book were used in the author's home for generations, but some of them were also found by her from other publications (Wojciechowska, 2014).

Based on the culinary heritage of the city, hotel administrators can create a gastronomic product which is unique for a given area. As a result of growing food awareness, customers pay significantly more attention to the ingredients and origins of products. Using local products from a given region has an influence on the perception of the hotel's brand, as well as building the image of the restaurant as one that supports small entrepreneurs and a hotel which cares about the quality of the food it serves.

\section{GASTRONOMIC PRODUCT ACCESSIBILITY IN ŁÓDŹ HOTELS}

The author chose two features from the research which she interpreted as the accessibility of gastronomic products in hotels: opening times and the distance of the restaurants from the ten most popular historical monuments of Łódź listed on the TripAdvisor website (TripAdvisor).

In Poland, restaurants (except those situated in accommodation facilities) are usually open for the whole day, with no breaks, contrary to 'Mediterranean culture' where restaurants are closed for the 'siesta' time, between 13.00 and 17.00 depending on the country. It is common practice that dinner/lunch in Europe is usually eaten between 14.00 and 16.00; in Western Europe it is earlier between 12 and 14.00; while in Central and Eastern Europe it is later. In many countries, however, it is the meal eaten after 18.00 that is the most varied and sophisticated (Sala, 2011).

The hotel restaurants in Łódź include some which are open for the whole day, some that are open with a break at lunch/dinner time, and those which are open twice - at breakfast time and in the afternoon. It depends on the additional activities run by the hotel. At hotels which organize conferences, restaurants are often reserved for conference groups at lunch time while large hotels close their restaurants after breakfast. During the break, some changes are often made, e.g. changing the waiting service, the cooks or decor, 
and the restaurant is opened again from the afternoon. In Łódź, there are 16 facilities where the restaurant is open without any break (Fig. 3). Breaks may make using the restaurant difficult for potential customers who cannot freely use it according to their needs or habits resulting from their cultural background.

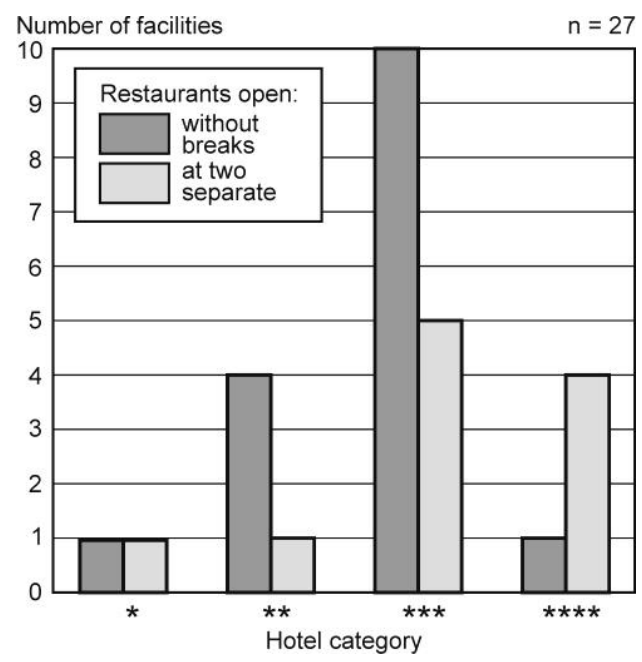

Fig. 3. Opening hours of hotel restaurants by hotel category

Source: author, based on own research

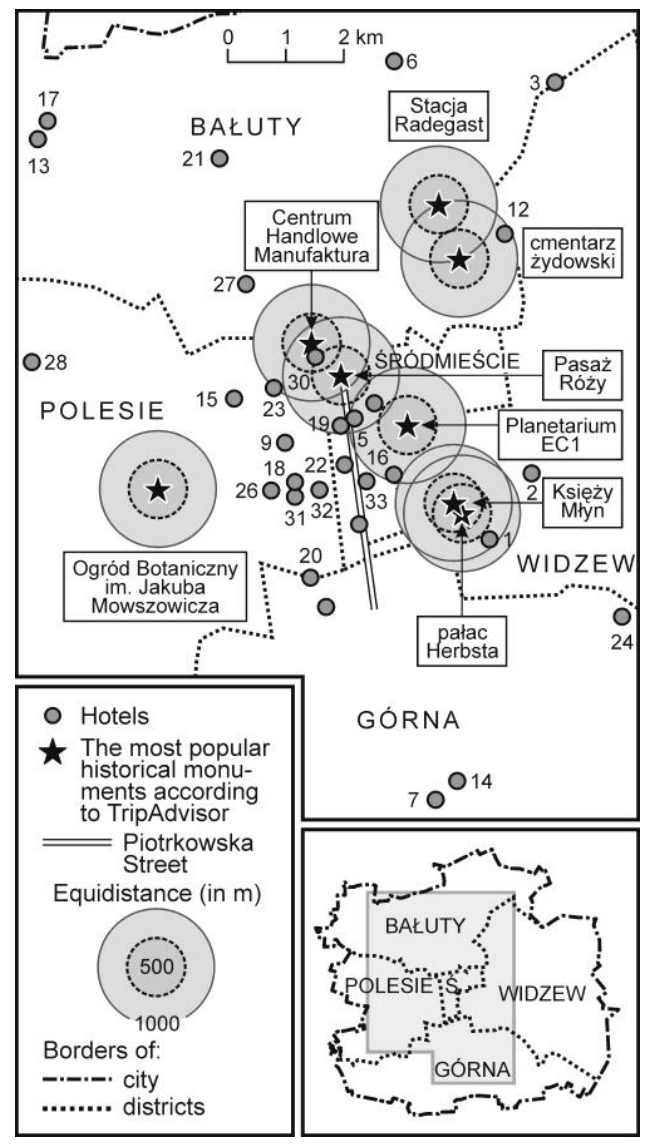

Fig. 4. The distribution of hotels in relation to selected sites in Łódź

Source: author, based on TripAdvisor
The next important argument stressed by the author is the location of the restaurant in relation to the ten most popular sites in Łódź mentioned on the TripAdvisor portal. The website presents a ranking of the most popular places, based on users' opinions and posts. In Łódź, eight individual sites were distinguished (Manufaktura Centre, Museum of Independence Traditions in Łódź - Radegast Station, the Jewish Cemetery, Księży Młyn district, Herbst Palace, Pasaż Róży, EC1 Planetarium, Jakub Mowszowicz Botanical Garden), Piotrkowska Street (the whole street, not individual places) and the area of the Eagiewnicki Forest. Eleven out of 27 hotels are located near at least one of those sites. The Grand Hotel and Holiday Inn are situated on Piotrkowska Street (Fig. 4).

The closeness of hotels to these sites influences hotel gastronomy in two ways - as a factor which makes tourists choose the hotel (they want to stay near the historical or tourist site of their choice), but after visiting the site the tourist may also want to use the hotel restaurant (not necessarily staying at the hotel for the night).

\section{SUMMARY}

Table 3 presents Łódź hotels which include restaurants. The author evaluates the hotel gastronomic product with respect to the features discussed earlier. The rating scale ranges from ' 0 ' for failing to meet the requirement to ' 1 ' for accomplishing it. 0 or 1 was allocated for a location close to historical monuments, regardless of the number of nearby hotels. Six facilities obtained the maximum number of points, one obtained 4 points (Tobaco Hotel - 'U Kretschmera' restaurant), five -3 points and four -0 points.

The restaurants selected for the study deserve particular attention, especially the ' $U$ Kretschmera' Restaurant at the Tobaco Hotel and the Delight Restaurant at Vienna House Andel's Łódź (Vienna House; Hotel Tobaco). Both these hotel restaurants have already been appreciated several times in various culinary competitions and highly rated in the Gault, Millau Yellow Guide, which is a prestigious publishing series (next to the Michelin guides) reviewing the gastronomic market (Horecanet.pl). Out of 640 restaurants in Poland which were distinguished for 2019, 18 can be found in Łódź, including two located in hotels. 'U Kretschmera' Restaurant has been awarded four times (in five Polish editions of the competition) (Koper, 2018).

When analysing the many aspects of Łódź gastronomy and deliberating over the chances to promote the culinary tourist attractions of the city, Stasiak (2015) did not discuss the topic of gastronomy in hotels. In the author's opinion, proper promotion of hotel gastronomy may, however, break the negative and untrue 
Table 3. The gastronomic product in Łódź hotels with restaurants

\begin{tabular}{|c|c|c|c|c|c|c|c|c|c|c|}
\hline \multicolumn{3}{|c|}{ Hotel } & \multicolumn{8}{|c|}{ Features of a hotel's gastronomic product } \\
\hline \multirow{2}{*}{ name $^{\mathrm{a}}$} & \multirow{2}{*}{ category } & \multirow{2}{*}{$\begin{array}{l}\text { restaurant } \\
\text { name }\end{array}$} & \multirow{2}{*}{$\begin{array}{c}\text { Name of } \\
\text { establishment }\end{array}$} & \multirow{2}{*}{\begin{tabular}{|c|} 
Local \\
cuisine \\
related to \\
the city's \\
traditions
\end{tabular}} & \multirow{2}{*}{$\begin{array}{c}\text { Opening } \\
\text { hours }\end{array}$} & \multicolumn{3}{|c|}{$\begin{array}{l}\text { Distance from selected historical } \\
\text { monuments }\end{array}$} & \multirow{2}{*}{$\begin{array}{c}\text { Location in } \\
\text { a historical } \\
\text { building }\end{array}$} & \multirow{2}{*}{ Tota } \\
\hline & & & & & & $\begin{array}{l}\text { Acces- } \\
\text { sibility }\end{array}$ & $0.5 \mathrm{~km}$ & $1 \mathrm{~km}$ & & \\
\hline Nu Hotel (2) & * & HR & 0 & 0 & 0 & 0 & 0 & 0 & 0 & 0 \\
\hline Alicja (4) & ** & HR & 0 & 0 & na & 0 & 0 & 0 & 0 & 0 \\
\hline $\begin{array}{l}\text { Ambasador } \\
\text { Chojny (14) }\end{array}$ & $* * *$ & HR & 0 & 0 & 0 & 0 & 0 & 0 & 0 & 0 \\
\hline Qubus (22) & $* * *$ & HR & 0 & 0 & 0 & 0 & 0 & 0 & 0 & 0 \\
\hline $\begin{array}{l}\text { Mazowiecki } \\
\text { (9) }\end{array}$ & $* *$ & 100łówka & 1 & 0 & 0 & 0 & 0 & 0 & 0 & 1 \\
\hline Mhotel (13) & $* * *$ & HR & 0 & 0 & 1 & 0 & 0 & 0 & 0 & 1 \\
\hline $\begin{array}{l}\text { Iness Hotel } \\
(20)\end{array}$ & $* * *$ & HR & 0 & 0 & 1 & 0 & 0 & 0 & 0 & 1 \\
\hline Rubin (24) & $* * *$ & HR & 0 & 0 & 1 & 0 & 0 & 0 & 0 & 1 \\
\hline Yuca (28) & $* * *$ & HR & 0 & 0 & 1 & 0 & 0 & 0 & 1 & 1 \\
\hline \begin{tabular}{|l} 
Doubletree \\
By Hilton \\
Łódź (31) \\
\end{tabular} & $* * * *$ & Four Colors & 1 & 0 & 0 & 0 & 0 & 0 & 0 & 1 \\
\hline Flora (17) & $* * *$ & HR & 0 & 0 & 1 & 0 & 0 & \begin{tabular}{|l|} 
\\
\end{tabular} & 0 & 1 \\
\hline \begin{tabular}{|l|} 
Ambasador \\
Centrum (29) \\
\end{tabular} & $* * * *$ & HR & 0 & 0 & 1 & 1 & $\begin{array}{c}\text { Piotrkowska } \\
\text { St. } \\
\end{array}$ & \begin{tabular}{|c|} 
Planetarium \\
EC1 \\
\end{tabular} & 0 & 2 \\
\hline Agat (3) & $* *$ & HR & 0 & 0 & 1 & 1 & $\begin{array}{c}\text { Łagiewnicki } \\
\text { Forest area } \\
\end{array}$ & 0 & 0 & 2 \\
\hline Ibis (8) & $* *$ & $\mathrm{HR}$ & 0 & 0 & 1 & 1 & \begin{tabular}{|c|} 
Piotrkowska \\
St.
\end{tabular} & 0 & 0 & 2 \\
\hline $\begin{array}{l}\text { Borowiecki } \\
(15)\end{array}$ & $* * *$ & $\begin{array}{l}\text { Tkalnia } \\
\text { Smaków }\end{array}$ & 1 & 0 & 1 & 0 & 0 & 0 & 0 & 2 \\
\hline $\begin{array}{l}\text { Focus } \\
\text { Hotel (18) }\end{array}$ & $* * *$ & HR & 0 & 0 & 1 & 0 & 0 & 0 & 1 & 2 \\
\hline $\begin{array}{l}\text { Nobo Hotel } \\
(21)\end{array}$ & $* * *$ & Kolory Wina & 1 & 0 & 1 & 0 & 0 & 0 & 0 & 2 \\
\hline $\begin{array}{l}\text { Światowit } \\
(25)\end{array}$ & $* * *$ & HR & 0 & 0 & 1 & 1 & $\begin{array}{c}\text { Piotrkowska } \\
\text { St. }\end{array}$ & 0 & 0 & 2 \\
\hline Vigo (27) & $* * *$ & Lawasz & 1 & 0 & 1 & 0 & \begin{tabular}{|l|}
0 \\
\end{tabular} & \begin{tabular}{|l|}
0 \\
\end{tabular} & 0 & 2 \\
\hline $\begin{array}{l}\text { Novotel Łódź } \\
\text { Centrum (33) }\end{array}$ & $* * * *$ & HR & 0 & 0 & 1 & 1 & 0 & \begin{tabular}{|c|}
$\begin{array}{c}\text { Piotrkowska } \\
\text { St. }\end{array}$ \\
\end{tabular} & 0 & 2 \\
\hline $\begin{array}{l}\text { Campanile } \\
\text { (16) }\end{array}$ & $* * *$ & HR & 0 & 0 & 1 & 1 & 0 & \begin{tabular}{|c|} 
Piotrkowska \\
St., Księży \\
Młyn, \\
Planetarium \\
EC1 \\
\end{tabular} & 0 & 2 \\
\hline Skarpa (12) & $* *$ & Skarabeusz & 1 & 0 & 1 & 1 & 0 & \begin{tabular}{|c|} 
Jewish \\
Cemetery
\end{tabular} & 0 & 3 \\
\hline $\begin{array}{l}\text { Holiday Inn } \\
\text { Łódź (32) }\end{array}$ & $* * * *$ & Łódzka & 1 & 1 & 0 & 1 & $\begin{array}{c}\text { Piotrkowska } \\
\text { St. }\end{array}$ & 0 & 0 & 3 \\
\hline Boss (1) & $*$ & $\begin{array}{l}\text { Polskie } \\
\text { Smaki }\end{array}$ & 1 & 0 & 1 & 1 & 0 & $\begin{array}{c}\text { Księży Młyn, } \\
\text { Herbst } \\
\text { Palace } \\
\end{array}$ & 0 & 3 \\
\hline $\begin{array}{l}\text { Grand } \\
\text { Hotel (19) }\end{array}$ & $* * *$ & Grand & 1 & 0 & 0 & 1 & $\begin{array}{c}\text { Piotrkowska } \\
\text { St. }\end{array}$ & \begin{tabular}{|c|} 
Pasaż Róży, \\
Planetarium \\
EC 1
\end{tabular} & 1 & 3 \\
\hline $\begin{array}{l}\text { Andel`S } \\
\text { Hotel Łódź } \\
\text { (30) }\end{array}$ & & Delight & 1 & 0 & 0 & 1 & $\begin{array}{c}\text { Piotrkowska } \\
\text { St. }\end{array}$ & \begin{tabular}{|c|} 
Pasaż Róży, \\
Planetarium \\
EC 1
\end{tabular} & 1 & 3 \\
\hline Tobaco (26) & & $\begin{array}{c}\text { U Kret- } \\
\text { schmera }\end{array}$ & 1 & 1 & 1 & 0 & 0 & 0 & 1 & 4 \\
\hline
\end{tabular}

a Marked on the map.

Key: ' 1 ' - yes, ' 0 ' - no, HR - hotel restaurant, na - not applicable.

Source: author. 
stereotype of 'catering facilities available only to the hotel guests', as well as reach out for a new group of customers interested in culinary tourism. A separate name for a restaurant, different from the hotel's name, can make advertising more effective, particularly in the social media. Establishing fixed opening hours will help to increase the accessibility of restaurants, as well as encourage those who are not hotel guests to have a meal there. The proximity of the most important historical monuments of Łódź should encourage restaurant managers to cooperate with city guides.

By using hotel catering facilities, especially those situated in historical buildings, where the dishes refer to the history of the city, the inhabitants and tourists gain an opportunity to see Łódź from a completely different perspective. They may discover and admire the original interiors of Łódź palaces and factories while trying new dishes, and their visit to the restaurant may be a pretext to tell stories about city inhabitants from the past. On the other hand, the hoteliers may gain a chance to promote themselves and increase their profits, as well as have an additional source of inspiration to create the brand of their hotel, fitting it perfectly into the history of the city.

\section{BIBLIOGRAPHY}

Björk, P., Kauppinen-Räisänen, H. (2017). A destination's gastronomy as a means for holiday well-being. British Food Journal, 119 (7), 1578-1591.

Centralna Ewidencja i Wykazy w Turystyce, Ministerstwo Turystyki. Retrieved from: www.turystyka.gov.pl (20.01.2019).

Czarnecka-Skubina, E., Głuchowski, A., Rasińska, E. (2017). Rynek Usług Gastronomicznych w Polsce na przykładzie Warszawy. Handel Wewnętrzny, 4 (369/2), 118-133.

Dziennik Łódzki. Retrieved from: www.dzienniklodzki.pl/ tradycyjna-lodzka-kuchnia-w-hotelu-holiday-inn-zdjeciafilm/ ar/3803633 (20.01.2019).

Gordin, V., Trabskaya, J., Zelenskaya, E. (2016). The role of hotel restaurants in gastronomic place branding. International Journal of Culture, Tourism and Hospitality Research, 10, 81-90.

Grand Hotel Łódź. Retrieved from: www.grand.hotel.com.pl (20.01.2019).

Grzegorczyk, A. (2005). Marka jest nazwą. Definiens marki. In: A. Grzegorczyk (ed.), Instrumenty ksztattowania wizerunku marki (1-7). Warszawa: Wyższa Szkoła Promocji.

Horecanet.pl. Retrieved from: www.horecanet.pl/piata-galazoltego-przewodnika-gault-millau-za-nami/ (20.01.2019).

Hotel Tobaco. Retrieved from: www.hoteltobaco.pl (20.01.2019).

InterSIT. Retrieved from: www.mapa.lodz.pl (20.01.2019).

Jędrysiak, T., Orłowski, D., Woźniczko, M. (2015). Turystyka kulinarna. Warszawa: PWE.

Kapera, I. (2015). Hotel gastronomy as viewed by customers. Food Journal, 117, 2993-3002.

Koper, H. (2018). Coraz więcej łódzkich restauracji wyróżnionych $w$ "Żóttym przewodniku Gault \& Millau". Retrieved from: www.lodz.travel/aktualnosci-lodzkiej-organizacji-turystycz nej/artykul-lot/coraz-wiecej-lodzkich-restauracji-wyroznio nych-w-zoltym-przewodniku-gault-millau-id24650/2018/ $11 / 29$ / (20.01.2019).

Kotler, P. (1994). Marketing. Analiza, planowanie, wdrażanie i kontrola. Warszawa: Gebethner \& Ska.

Kozłowska, A. (2015). Wybrane wydarzenia gastronomiczne w Łodzi jako efekt trendów europejskich. In: B. Krakowiak, A. Stasiak (eds), Kultura i turystyka - wokót wspólnego stołu (pp. 333-356). Łódź: Regionalna Organizacja Turystyczna Województwa Łódzkiego oraz Instytut Geografii Miast i Turyzmu Uniwersytetu Łódzkiego.

Krakowiak, B., Stasiak, A. (eds) (2015). Kultura i turystyka - wokót wspólnego stołu. Łódź: Regionalna Organizacja Turystyczna Województwa Łódzkiego oraz Instytut Geografii Miast i Turyzmu Uniwersytetu Łódzkiego.

Kuchniewska, M. (2013). Media społecznościowe jako narzędzie nowoczesnego marketingu usług hotelarskich. In: P. Dominik (ed.), Innowacyjne rozwiazania we wspótczesnym hotelarstwie (pp. 106-121). Warszawa: Almamer.

Kwiatkowska, E., Levytska, G. (2009). Rynek usług gastronomicznych w Polsce na początku XXI w. Zeszyty Naukowe SGGW Ekonomika i Organizacja Gospodarki Żywnościowej Warszawa, 74, 91-102.

Milewska, M., Prączko, A., Stasiak, A. (2017). Podstawy gastronomii. Od żywności do turystyki kulinarnej. Warszawa: PWE.

Milewska, M., Włodarczyk, B. (2015). Hotelarstwo. Podstawowe wiadomości. Warszawa: PWE.

Ministerstwo Rolnictwa i Rozwoju Wsi. Retrieved from: www.gov.pl/web/rolnictwo/produkty-regionalne-i-tra dycyjne1 (20.01.2019).

Rozporzadzenie Ministra Gospodarki i Pracy z 19.08.2004 r. w sprawie obiektów hotelarskich i innych obiektów, w których sa świadczone ustugi hotelarskie. DzU. 2004, nr 188, poz. 1945.

Sala, J. (2011). Marketing w gastronomii. Warszawa: PWE.

Stasiak, A. (2007). Gastronomia jako produkt turystyczny. Turystyka $i$ Hotelarstwo, 11, 103-129.

Stasiak, A. (2015). Gastronomia jako atrakcja turystyczna Łodzi. Turyzm, 25 (2), 77-90.

TripAdvisor. Retrieved from: www.pl.tripadvisor.com/Attrac tions-g274837-Activities-Lodz_Lodz_Province_Central_Poland. html (20.01.2019).

Ustawa z 29.08.1997 r. o ustugach hotelarskich oraz ustugach pilotów wycieczek i przewodników turtycznych. DzU. 1997, nr 133, poz. 884

Vienna House. Retrieved from: www.viennahouse.com (20.01.2019).

Włodarczyk, B. (2015). Hotele w przestrzeni miejskiej Łodzi. Tourism/ Turyzm, 25 (2), 63-75.

Wojciechowska, A. (2014). Fifka i żulik, czyli domowa kuchnia Łódzka. Łódź: Centrum Inicjatyw na Rzecz Rozwoju „Regio”.

Wojewódzki Urząd Ochrony Zabytków w Łodzi, 2018. Retrieved from: www.wuoz-lodz.pl/Rejestr_i_ewidencja_zabytkow,19 (20.01.2019).

Wrona, D., Armatys, K. Marka. Retrieved from: https://mfiles.pl/ $\mathrm{pl} /$ index.php/Marka (20.01.2019).

Article received: 6 January $2019 \mathrm{r}$. Accepted:

1 March 2019 r. 